\title{
Progress in Surgery
}

\section{Vol. 25}

Series Editors

M.W. Büchler, Bern

E.H. Farthmann, Freiburg i. Br.

KARGER $\begin{aligned} & \text { Basel·Freiburg } \cdot \text { Paris } \cdot \text { London } \cdot \text { New York } \\ & \text { New Delhi } \cdot \text { Bangkok } \cdot \text { Singapore } \cdot \text { Tokyo } \cdot \text { Sydney }\end{aligned}$ 


\title{
Acute Appendicitis: Standard Treatment or Laparoscopic Surgery?
}

\author{
Volume Editors $\quad$ L. Krähenbühl, Bern \\ E. Frei, Bern \\ Ch. Klaiber, Aarberg \\ M.W. Büchler, Bern
}

58 figures, 21 in color, and 31 tables, 1998

KARGER $\begin{aligned} & \text { Basel } \cdot \text { Freiburg } \cdot \text { Paris } \cdot \text { London } \cdot \text { New York } \\ & \text { New Delhi } \cdot \text { Bangkok } \cdot \text { Singapore } \cdot \text { Tokyo } \cdot \text { Sydney }\end{aligned}$ 


\section{Lukas Krähenbühl, MD}

Assistant Professor of Surgery Department of Visceral and

Transplantation Surgery

University Hospital of Bern

Switzerland

\section{Christian Klaiber, MD}

Chairman Department of Surgery

Aarberg Hospital

Switzerland

\section{Edgar Frei, MD}

Department of Surgery

Lindenhofspital

Bern

Switzerland

\section{Markus W. Büchler, MD}

Professor of Surgery

Chairman Department of Visceral and

Transplantation Surgery

University Hospital of Bern

Switzerland

Library of Congress Cataloging-in-Publication Data

Acute appendicitis:standard treatment or laparoscopic surgery?/volume editors, L. Krähenbühl... [et al.] (Progress in surgery; vol. 25)

Includes bibliographical references and indexes

1. Appendectomy. 2. Appendicitis - Endoscopic surgery.

I. Krähenbühl, L. (Lukas) II. Series.

[DNLM: 1. Appendicitis - surgery. 2. Surgical Procedures, Laparoscopic - methods

W1 PR681M v.25 1998/WI 535 A189 1998]

RD542.A28 1998

$617.5^{\prime} 545-\mathrm{dc} 21$

ISBN 3-8055-6641-7 (hardcover: alk. paper)

Bibliographic Indices. This publication is listed in bibliographic services, including Current Contents ${ }^{\circledR}$.

Drug Dosage. The authors and the publisher have exerted every effort to ensure that drug selection and dosage set forth in this text are in accord with current recommendations and practice at the time of publication. However, in view of ongoing research, changes in government regulations, and the constant flow of information relating to drug therapy and drug reactions, the reader is urged to check the package insert for each drug for any change in indications and dosage and for added warnings and precautions. This is particularly important when the recommended agent is a new and/or infrequently employed drug.

All rights reserved. No part of this publication may be translated into other languages, reproduced or utilized in any form or by any means electronic or mechanical, including photocopying, recording, microcopying, or by any information storage and retrieval system, without permission in writing from the publisher.

(C) Copyright 1998 by S. Karger AG, P.O. Box, CH-4009 Basel (Switzerland)

Printed in Switzerland on acid-free paper by Reinhardt Druck, Basel

ISBN 3-8055-6641-7 


\section{Contents}

Appendicitis: Pathogenetic Background

1 History of 'Right Iliac Fossa Pain': From Internal to Surgical Treatment - With Special Reference to the Evolution in Switzerland

Boschung, U. (Bern)

10 Epidemiology, Etiology and Pathogenesis of Acute Appendicitis Maurer, C.A.; Renzulli, P.; Wildi, S.; Schneider, M. (Bern)

18 Appendicitis: Histopathology and Classification Zimmermann, A. (Bern)

27 The Role of Nerves in Pain Generation Di Sebastiano, P. (Pescara); Fink, T.; Weihe, E. (Marburg); di Mola, F.F. (Pescara/Bern); Friess, H. (Bern); Beger, H.G. (Ulm); Innocenti, P. (Pescara); Büchler, M.W. (Bern)

34 The Role of Antimicrobial Therapy Telenti, A. (Bern)

38 Clinical Pictures and Differential Diagnosis Säuberli, H.; Tedaldi, R. (Baden)

Diagnosis, Decision-Making and Standard Surgery

43 Decision-Making in Acute Appendicitis

Ohmann, C.; Franke, C.; Böhner, H.; Imhof, M.; Röher, H.D. (Düsseldorf)

53 Early versus Delayed Surgical Treatment of Acute Appendicitis Sussman, L.A.E.; Paterson-Brown, S. (Edinburgh)

59 Standard Open Surgical Technique in Appendicitis: From the Past to the Present

Seiler, Ch.A. (Bern) 
70 Complications of Open Appendectomy Vogelbach, P.; Oertli, D.; Thalmann, Ch.; Frede, K.; Harder, F. (Basel)

73 Negative Appendectomy: Is It Always Negative? Puri, P.; Xiong, S.-G.; Reen, D.J. (Dublin)

State-of-the-Art

78 Appendiceal Neoplasms Schmid, S.W.; Modlin, I.M. (New Haven, Conn.)

Laparoscopic Treatment of Acute Appendicitis

93 Standard Laparoscopic Technique in Adults Krähenbühl, L.; Schäfer, M.; Farhadi, J.; Büchler, M.W. (Bern)

101 Laparoscopic Treatment of Acute Appendicitis: Standard Technique in Children

Müller, C.; Bugmann, Ph.; Lironi, A.; Le Coultre, C. (Geneva)

109 A Meta-Analysis of Studies Comparing Laparoscopic with Conventional Appendectomy

Sauerland, S.; Lefering, R.; Holthausen, U.; Neugebauer, E. (Cologne)

International Results of Open versus Laparoscopic Appendectomy

115 Laparoscopic Appendectomy in France - A Multicenter Study Fingerhut, A. (Poissy); Pélissier, E.P. (Besançon); Millat, B. (Montpellier); Hay, J.-M. (Colombes); Blum, D. (Besançon); Desrousseaux, B. (Lomme); Levard, H. (Paris), French Associations for Surgical Research (Bois-Colombes)

126 Open versus Laparoscopic Appendectomy Studies and Results from Germany

Hildebrandt, U.; Frank, J.; Feifel, G. (Homburg/Saar)

131 Standard Treatment and the Role of Laparoscopic Surgery The Austrian Experience

Shamiyeh, A.; Wayand, W.U. (Linz)

135 Laparoscopic Appendectomy in the Netherlands Bonjer, H.J.; Kazemier, G.; Lange, J.F. (Rotterdam); van Erp, W.F.M. (Eindhoven); Cuesta, M.A. (Amsterdam)

138 Laparoscopic Appendectomy in Switzerland: SALTS Analysis Schäfer, M.; Krähenbühl, L.; Borer, D.; Klaiber, Ch.; Frei, E. (Bern)

145 Open versus Laparoscopic Appendectomy: View from the USA Soper, N.J. (St. Louis, Mo.)

149 Open versus Laparoscopic Appendectomy - The Australian Experience Mouton, W.G.; Wemyss-Holden, S.A.; Otten, K.T.; Maddern, G.J. (Woodville South)

Safe Performance of a Laparoscopic Appendectomy

155 Diagnostic Laparoscopy in Acute Pain of the Right Lower Abdomen Wagner, St.; Clerici, Th.; Nägeli, J.; Zünd, M.; Lange, J. (St. Gallen) 
159 Laparoscopic Appendectomy: A Beginner's Operation? Gianom, D.; Schöb, O.; Schlumpf, R. (Zürich)

165 Standard Technique of Laparoscopic Stapling Appendectomy Wagner, M. (Bern); Borer, D.; Klaiber, Ch. (Aarberg)

173 Transumbilical Video-Assisted Appendectomy Begin, G.F. (Dijon)

178 Gynecological Findings for Right Iliac Fossa Pain Maurer, F.; Stucki, D. (Freiburg)

Conclusion

185 Acute Appendicitis: Standard Treatment or Laparoscopic Surgery? Krähenbühl, L.; Frei, E.; Klaiber, Ch.; Büchler, M.W. (Bern)

187 Author Index

188 Subject Index 